\title{
Obituary \\ Dr David D Yen, JD (1921-2002)
}

"I see every single day as a treasure waiting for me to cherish it" - Dr David Yen

Dr David Yen, one of the three "grandfathers" of tobacco control in Asia (along with the late Dr Takeshi Hirayama in Japan and Dr Weng Xin Zhi in China), died in Taipei on 6 September 2002 at the age of 82 years, leaving a wife and four children.

Dr Yen was born to a well-off family in Shanghai in 1921. After graduating from Suzhou University Law School in 1943, he was a research fellow in economics at the Imperial University of Kyoto from 1943 to 1944, and then obtained a doctorate from Indiana University's School of Law in 1949. After finishing his studies, Yen went into business in Brazil, then finally settled in Taiwan in 1965. He mastered six languages including Japanese, Spanish, Portuguese, and English.

He started smoking at the age of 11 years and chain smoked 40 cigarettes a day for over 40 years. This led to removal of his right lung at the age of 52. From that moment on, he dedicated his life to reducing tobacco use

In 1984, he founded the John Tung Foundation in Taipei, which works in four main fields: tobacco control, mental health, nutrition, and the environment. The foundation is still the best example of NGO-government collaboration in Asia, with the two sides working both separately and together, and each respecting the other's roles. This is remarkable in a region where NGOs have traditionally been viewed with suspicion by governments and even banned.

Dr Yen's influence spread to prime ministers, public officials, film stars, and youth groups. He persuaded the media to provide free and extensive media coverage, which was successful because he imbued health education with creativity. He also lobbied intensively for tobacco control legislation, and gave much of his own savings to support this work.

During the 1980s, the storm clouds of section 301 of the 1974 US Trade Act were gathering over Asia, with the trade arm of the US government threatening

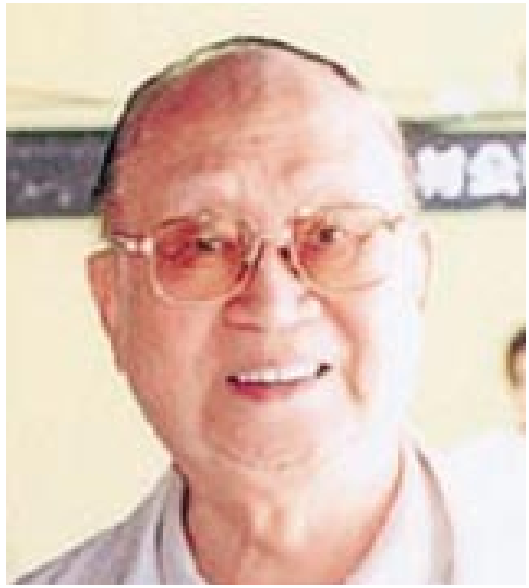

several countries in the region with unilateral trade sanctions unless these countries opened their markets to, and allowed advertising of, US tobacco products, even in countries with national advertising bans.

Dr Yen decided that a regional organisation and a pan-Asian strategy were needed to combat these threats, so in 1989 he founded and funded the Asia Pacific Association for the Control of Tobacco (APACT), of which he later became Honorary Life President. To help Thailand resist these trade pressures, APACT submitted a petition to the US government, urging it to stop using section 301 for tobacco exports and, in cooperation with US health leaders, lobbied the US Congress.

When APACT was founded, Asian countries were rarely in contact with one another, and initially APACT consisted of only a few members: Hong Kong, Indonesia, Japan, Malaysia, the Republic of Korea, Philippines, Singapore, Taiwan, and Thailand, along with Canada and the USA.

Since then, APACT has organised a major regional conference every few years, in Taipei (1989), the Republic of Korea (1991), Japan (1993), Thailand (1995), the Philippines (1998), Taipei (1999), and Hong Kong (2001). The next meeting will be in Seoul in 2004. Participants from countries as diverse as
Australia, the Pacific Islands, and Mongolia come together to share experiences and learn from one another. Currently, APACT has members from all the countries in the region, including China. David Yen's vision of an Asian family has become reality.

Dr Yen was remarkable on several fronts. He was one of the kindest, most generous men I have known. He was renowned for training new campaigners in tobacco control. Although in his early days, he would give up to 500 lectures a year to schools, I can't remember when he last gave a speech; he would always sit quietly in the audience while his young workers took to the podium and spoke about their work. I know of no other leader who was so dedicated to passing on knowledge and expertise.

He was an instinctive and indefatigable coalition builder. He was always negotiating for others to work together, which often required considerable diplomatic skills.

His health failed in his latter years, but this did not deter him from his legendary optimism: "I understand the meaning of life and I respect all lives as much as my own. I have never regretted what I have done and I see every single day as a treasure waiting for me to cherish it," he said.

Dr Yen's relentless devotion to the anti-tobacco movement won him the title of "Lin $\mathrm{Zhe} \mathrm{Xu}$ of the modern world" after the Qing dynasty official whose ban on the import of opium led to the Opium War over 160 years ago.

Without exception, tobacco control advocates around Asia revered Dr Yen for his work. He also received many honours and awards, including the World Health Organization Commemorative Medal, a prestigious royal award from the King of Thailand, and a Buddhist Compassion Award. Reading that he had also received "The Man With Good Heart Award" made me smile and remember him fondly.

Judith Mackay, Asian Consultancy on Tobacco Control imackay@pacific.net.hk 